This article is (c) Emerald Group Publishing and permission has been granted for this version to appear here http://eprints.kingston.ac.uk . Emerald does not grant permission for this article to be further copied/distributed or hosted elsewhere without the express permission from Emerald Group Publishing Limited.

\title{
Introduction
}

Investigating organisation and management phenomena through an identity frame has provided a novel conceptual lens for revitalising established areas of research (Alvesson et al., 2008). Identity is at the centre of meaning and decision-making, motivation, action and commitment, loyalty, stability and change (Sveningsson and Alvesson, 2003). Early notions of identity had a tendency towards biological reductionism; identity was treated as an entity with stable qualities derived from characteristics such as sex, which determine behaviour. Such strong essentialist views are now widely recognised as wrong and misleading (Somers, 1994; Sayer, 1997; O'Mahoney, 2012). Contemporary organisation scholars tend to conceptualise identity in processual and relational terms, emphasising the role of language and discourse in the formation of identity (Sveningsson and Alvesson, 2003; Watson, 2008). Entrepreneurial identity has been described as a dynamic, fluid and often contradictory process (Hytti, 2005), constituted by a range of narrative and discursive practices performed in relation to the social environment (Down, 2006; Watson, 2009). Studies are typically concerned with how entrepreneurs narratively construct and negotiate their identities (Warren, 2004), and in doing so present themselves as legitimate to important business stakeholders in order to access resources and market opportunities (Lounsbury and Glynn, 2001).

While we agree that strong essentialism is always wrong, moderate forms of essentialism are necessary for the social sciences (Sayer, 1997; Elder-Vass, 2012; O'Mahoney, 2012). The essentialist notion of the self recognises that human beings possess properties and powers that influence their actions (O'Mahoney, 2012), including the capacity to form particular identities (Smith, C. 2010). Without such essential properties and powers, there could be no persons or selves; even scholars treating identity in terms of narrative and discursive practices necessarily presuppose the existence of agents possessing the powers to perform such practices or to be shaped by them. We contribute to the entrepreneurial identity literature by critiquing studies' privileging of linguistic practices to the neglect of non-linguistic practices, such as bodily movement, posture, gestures and facial expressions. Identity is of course expressed through narrative and shaped by discourse, but it is irreducible to neither.

From our realist, moderate constructionist viewpoint, social objects exist independently of, and prior to, their identification by researchers (Bhaskar, 1978, 1979; Archer, 1995; Sayer, 1992). 
Entrepreneurial identity, as a real social object, is therefore distinct from any particular conception of it. This prior, independent existence is what makes it a possible object of study although, of course, it also means we might misperceive and misunderstand it. We conceptualise entrepreneurial identity as a set of concerns emergent from the embodied practices of agents committed to new venture creation and management. Accounts that reduce identity to linguistic practices are incomplete without reference to a non-discursive reality (O'Mahoney, 2012). Agents cannot simply describe themselves as entrepreneurs and expect to have their narratives accepted by important others. Our contribution to the literature is to emphasise the role of the body and embodied non-linguistic practices in the formation of identity.

We use the term identity formation, drawing on Smith, C. (2010) and Archer (2000), to refer to the human capacity to create, negotiate, maintain and transform identity in relation to three analytical orders of reality: the natural, the practical and the social. This expands the notion of identity work (Sveningston and Alvesson, 2003; Watson, 2008, 2009) framed by Watson (2008: 130) as "a coming together of inward/internal self-reflection and outward/external engagementthrough talk and action - with various discursively available social-identities". For Watson, identity work involves other people telling us who we are and occurs in the context of institutional, cultural and discursive influences impinging on our sense of self. Identity work crucially highlights the interplay of social structure and agency, but for Watson, this occurs only in the social environments, through narrative and discursive practices. In contrast, we recognise that identity shapes, and is shaped by, embodied practices not only in the social context, through dialogue with others, but importantly also in relation to agents' natural and practical environments.

The paper draws extensively on the wider social science literature on embodiment - the idea that persons and selves cannot exist without the material body (Turner, 1984; Burkitt, 1999; Archer, 2000; Shilling, 2003; Smith, C. 2010). This may sound self-evident, yet the entrepreneurial identity literature typically takes the body for granted. Studies under-theorise the body and its influence on identity, with the effect of treating entrepreneurs analytically as disembodied, as lacking particular embodied properties and powers. Scholars, for instance, typically assume implicitly that entrepreneurs are able-bodied as opposed to differently-abled agents. With a few exceptions (Rouse, 2008, 2009; Clarke, 2011; Cornelissen et al., 2012), studies of entrepreneuring using the lens of embodiment are rare.

Critiquing and building on prior studies, our aim is to develop a novel conception of entrepreneurial identity, one that takes human embodiment seriously, and to consider the implications for research. We conceptualise entrepreneurs as differently-abled agents to illustrate 
how being embodied in a particular way shapes identity. Our conception in no way implies that identity constitutes a set of stable characteristics or behaviours. Like others (Watson, 2008), we recognise the dynamic processes of identity formation. We simply argue that agents' embodied properties and powers necessarily influence such processes; the power to form identity cannot be restricted to narrative or discourse. Although the proposed conception is intended to apply to all entrepreneurs, we discuss the implications for one particular group - entrepreneurs with impairments. [1] Embodied properties and powers, such as those associated with particular types of impairment, may present specific challenges or opportunities that would not have existed otherwise. By examining the potential effects of impairment on entrepreneurial activities, we elucidate the value of theorising identity through the lens of embodiment.

The paper is organised as follows. We first draw on the embodiment literature and the work of Archer and Goffman to develop a conception of entrepreneurial identity that takes embodied practice as a necessary precondition for the emergence of identity. We then critically review the entrepreneurial identity literature to show how the neglect of embodiment both reflects and reinforces several problematic assumptions, shaping empirical inquiry and thereby limiting understanding of entrepreneurial identity. And finally, we discuss the theoretical and methodological implications of the new framework for studying entrepreneurial identity before concluding the paper.

\section{Embodying entrepreneurial identity}

One of the powers of human beings is the capacity to form identities (Smith, C. 2010). Identity has been theorised extensively in the social sciences (Mead, 1938; Goffman, 1959, 1963; Giddens, 1991; Burkitt, 1999; Archer, 2000; Jenkins, 2008), with scholars often referring to two interdependent, but contradictory, aspects of personhood: the sense of self, or uniqueness as an individual; and the sense of sameness or group affiliations. In this interplay of internal selfidentification and external engagement (Watson, 2008), each person is uniquely embodied and their body necessarily influences their identity, at particular points in time and space. We draw on the embodiment literature (e.g. Turner, 1984), Archer's (2000) notion of identity and Goffman's $(1959,1963)$ ideas of presentation of self, impression management and stigma to elaborate a novel conception of embodied entrepreneurial identity.

\section{Embodied self}

Adopting the concept of embodiment, which frames the self as a unity of mind and body, scholars 
increasingly argue that who we are cannot be separated from how we are embodied (Turner, 1984; Burkitt, 1999; Archer, 2000; Shilling, 2003; Jenkins, 2008; Smith, C. 2010). Embodiment thinking seeks to overcome the Western philosophical tradition of mind-body dualism, which maintains the existence of two distinct realms - mind and matter. Embodiment studies have highlighted the role of the material body in conceptions of identity and personhood. Whilst the self cannot be reduced to the body, we could not be persons or selves without bodies enabling us to be active agents in the world (Burkitt, 1999). The cognitive processes constitutive of identity formation such as perception, reason, memory and language are embodied and grounded in the action of the physical body (Varela et al., 1991; Lakoff and Johnson, 1999; Burkitt, 1999; Gibbs, 2003, Farnell and Varela, 2008). Embodiment is integral to sense-making (Cunliffe and Coupland, 2011) and sensegiving (Cornelissen et al., 2012); we reflect on who we are as embodied agents (Crossley, 2006) and communicate to others through our embodied practices, including but also extending beyond the use of language. Bodily movement in particular is an important meaning-making resource (Farnell and Varela, 2008). Through movement, human beings communicate their conscious states such as beliefs, intentions and emotions, both purposefully and inadvertently. The practical action of embodied agents is central to Archer's (2000) conception of identity which we expand upon in the next section.

\section{Embodied practice and the emergence of identity}

Agents possess embodied properties and powers that influence their action in relation to the three orders of reality: the natural, the practical and the social (Archer, 2000). How we are embodied enables and constrains our practices, such as walking into the wind (natural order), using humanmade artefacts like computers and cars (practical order), performing social roles and communicating effectively with others (social order). Archer distinguishes three levels of identity, emergent from consciousness - the self, personal identity and social identity - which are intertwined but irreducible to each other.

Self, or the sense of self, is the most fundamental of human powers (Archer, 2000). It is what makes each of us a unique human being. The self emerges through our embodied relations with the natural environment independently of, and prior to, the development of linguistic competence. It arises at a very early stage of life as babies acquire awareness of themselves as materially embodied beings, separate from other physical objects in their environment, able to act causally on the material world. Archer emphasises the primacy of embodied practice as a source of the self. Human beings acquire practical knowledge that is non-linguistic before learning how to 
speak and continue bodily, non-linguistic, learning in relation to the natural environment throughout life. Thus, for the sense of self to emerge, embodied practices are more important than language acquisition; individuals acquire a sense of self even if they lack the capacity to speak. The formation of the self continues in relation to the practical environment as we learn how to use various human-made artefacts, and finally, through linguistic interaction. Whilst embodied practice is crucial for the emergence of the self, embodied memory is necessary for the continuous sense of self over time. Here, procedural embodied memories derived from the exercise of tacit bodily skills are more resilient than declarative or verbal memories and endure for a lifetime.

Personal identity, emergent from the sense of self, refers to the specific constellation of concerns that makes each of us a particular person (Archer, 2000). It encompasses what we care about most in our interactions with our natural, practical and social environments. Each person has a distinct set of concerns which shape, and are shaped by, embodiment in relation to each order of reality. Unlike the sense of self, which is held to be universal to all human beings, personal identity is an achievement, realised through an 'internal conversation'; it occurs only in maturity, and is not attained by all. Emotions fuel internal conversations and act as commentaries on agents' concerns. Thus, in the natural order, fear emerges from anticipation of known dangers, such as fire, as a commentary on our 'physical well-being'. In the practical order, joy or frustration emerge from the use of artefacts and act as commentaries on our concern with 'performative competence'. And in the social order, emotions such as pride or shame emerge in relation to other people as commentaries on our concern with 'self-worth'. To survive and thrive, we need to attend to our concerns in all three orders of reality simultaneously, although individuals will set their own priorities as to which concerns matter most. It is the balance that we strike between our various concerns that gives us our strict personal identity.

Social identity refers to the relationships and roles we are committed to in society; it can be seen as a sub-set of personal identity (Archer, 2000). While personal identity regulates our relations with all three orders of reality, a social identity can only be accomplished through social interaction. Social identity arises from our involuntary position at birth within society's distribution of resources, and from voluntarily identifying with particular social roles we feel we can invest ourselves in and become committed to. Archer emphasises that social identities emerge when agents voluntarily personify a particular social role which then becomes part of their personal identity. Yet, to achieve a desirable social identity, agents must meet the expectations of important others associated with the roles they wish to occupy. Being an entrepreneur is one such social role. We draw on Goffman $(1959,1963)$ next to elaborate how social expectations and embodiment 
influence agents' capacities to accomplish a desirable social identity.

\section{Embodied practice in the social order}

Social roles, such as entrepreneur, prescribe appropriate behaviours and appearances that reveal 'information' to others about the social identity of role occupants (Goffman, 1959). To adopt and perform a social role successfully, agents must conform to some degree to the behavioural and appearance norms associated with the role in order to satisfy the expectations of others (Goffman, 1959). Social roles shape but do not determine personal identity and behaviour; individual role incumbents are active agents capable of interpreting role requirements and acting upon them flexibly. Agents' ability to control information about their embodied practices and to make the right impression on others is crucial for their sense of self because to have a feeling of bodily integrity - the self being safely 'in' the body - is related to social approval (Giddens, 1991).

Social identities are formed, in part, intentionally, through the impressions we consciously make on others, and, in part, unintentionally, by virtue of being embodied in a certain way, involuntarily signalling particular meanings to others. These others reinforce or challenge such meanings through their actions. Agents possess the capacity to perceive, emote about, reflect and act upon their bodies, and to transform their body image, with the intention of achieving desirable social identities. Such reflexive embodiment (Crossley, 2006) involves a range of non-linguistic practices, including bodily movement, posture, gestures, facial expressions and the use of various artefacts as well as linguistic performance. At the same time, people are often unaware of the impressions their embodied practices make on others inadvertently or how this impacts the capacity to attend to their concerns. The visibility of 'undesirable' or stigmatising bodily attributes, such as particular types of impairment, and agents' variable capacity to control such information in social interaction, influences others' perceptions and reactions. Depending on circumstances and social relationships, the stigma associated with such undesirable attributes can affect individual capacity to achieve sought-after social identities and their related benefits (Goffman, 1963).

\section{Embodied entrepreneurial identity}

Building on the previous section, we conceptualise entrepreneurial identity as a set of concerns emergent from the embodied practices of agents committed to new venture creation and management in relation to their natural, practical and social environments. Particular embodied properties and powers continuously influence entrepreneurial identity. Agents' concerns in relation to the natural environment, such as the capacity to walk, necessarily influence their 
performative competence in the practical environment, for instance, the ability to use a computer or to drive a car, and ultimately, their capacities in relation to the social environment, such as communicating effectively and building legitimacy when interacting with important business stakeholders. Agents have to invest themselves in, and be committed to, the social role of an entrepreneur and to convince powerful stakeholders, including customers, finance providers, employees and others that they are legitimate actors in order to attain an entrepreneurial identity and the associated benefits. Entrepreneurs need both to 'fit in' with social norms and to 'stand out' as a rule-breaker in terms of their novel product offering (De Clercq and Voronov, 2009). This depends on their capacities to perform various embodied practices, non-linguistic as well as linguistic, in relation to all three orders of reality. Entrepreneurial identity cannot be reduced to linguistic performances.

\section{'Disembodied' entrepreneurs in the identity literature}

The dominant approach in the entrepreneurial identity literature is to conceptualise identity as a dynamic process constituted by a range of narrative or discursive practices, performed in relation to the social environment. This social constructionist approach to identity, according to Down (2010), overcomes mind-body dualism by challenging the existence of the self as a mind and by arguing that the self, and the mind itself, are socially constructed. Down recognises the biological basis of the self, but considers this of limited use to explain the social and economic significance of identity. The studies we review typically lean towards a strong constructionist view although, in some cases, there are elements of a more moderate approach. We follow Elder-Vass (2012) in defining strong constructionism as the view that the only reality we can have access to is a linguistically mediated one. Strong constructionism can be distinguished from more moderate forms which are essential to a robust conception of embodied entrepreneurial identity. Moderate constructionism permits variation in agents' linguistic expressions but does not reduce identity to such practices. Agents may express themselves in a variety of ways while retaining a specific set of concerns, although such concerns are of course dynamic and vary over time. In what follows, we set out the key features of entrepreneurial identity studies before critiquing their assumptions.

Scholars agree that entrepreneurial identity is not formed in isolation but in relation to significant others (Warren, 2004; Down and Reveley, 2004; Down, 2006; Jones et al., 2008; Watson, 2009). Identity is constructed and reconstructed dialogically, through stories or narratives (Hytti, 2005; Johansson, 2004; Warren, 2004; Essers and Benschop, 2007, 2009; Jones et al., 2008; Down, 2006; Down and Warren, 2008; Watson, 2009; Reveley and Down, 2010; Smith, R. 2010). 
Entrepreneurs narratively construct and negotiate their identities in order to present themselves as legitimate and credible to a range of important business stakeholders. To the extent they succeed, this enables entrepreneurs to access resources and market opportunities (Lounsbury and Glynn, 2001; Martens et al., 2007; Navis and Glynn, 2011).

Entrepreneurial identity, studies suggest, is formed by various discourses and discursive resources, including the enterprise discourse (Watson, 2009). Down (2010: 70) defines the discourse of enterprise as "...all the ways of talking about enterprise; the character of the entrepreneur and the moral expectations we have of enterprising acts... The discourse of enterprise will tend to prescribe what are legitimate acts and narratives for people who define themselves as entrepreneurs. We would want a very convincing narrative to be persuaded that an actuary, vicar or soldier was an entrepreneur: the discourse frames what is possible." People draw upon and reproduce, but also resist, the enterprise discourse (Cohen and Musson, 2000; Warren, 2004; Hytti, 2005; Essers and Benschop, 2007; Jones et al., 2008; Ainsworth and Hardy, 2008; Watson, 2009; Iyer, 2009; Anderson and Warren, 2011; Díaz García and Welter, 2013). Agents are often powerfully constituted by the discourse of enterprise (Warren, 2004; Essers and Benschop, 2007; Achtenhagen and Welter, 2011), empowered as entrepreneurs (Anderson and Warren, 2011), or excluded from it (Ainsworth and Hardy, 2008).

These studies reject strong essentialist views that conceive identity as determined by biological characteristics - we agree. Down and Reveley (2004), for instance, contrast themselves with psychological traits theorists who focus solely on individual personality characteristics to explain why people become entrepreneurs. The search for the entrepreneurial personality has contributed to the 'mythical status of entrepreneurs' as special people (Mitchell, 1997), a status reinforced by media representations of entrepreneurs as heroic individuals (Nicholson and Anderson, 2005; Anderson and Warren, 2011) or other stereotypes, such as the norm of the male entrepreneur (Achtenhagen and Welter, 2011). Entrepreneurial identity has instead been conceptualised as an emergent, dynamic, inconsistent and paradoxical process (Hytti, 2005; Essers and Benschop, 2007, 2009; Jones et al., 2008; Down and Warren, 2008). For instance, when medical doctors take on entrepreneurial functions, contradictions may arise between their role as a medical professional and their emergent entrepreneurial identity (Hytti, 2005). Both the role and the social meaning of the term 'entrepreneur' is dynamic and changes over time (Down, 2010). But while we agree that identity is dynamic, agents' embodied properties and powers may limit their ability to attain a particular social identity such as that of an entrepreneur.

Taking the materiality of human embodiment for granted, most entrepreneurial identity 
studies necessarily, though perhaps unintentionally, reproduce mind-body dualism. The serious neglect of the body in the literature produces a disembodied conception of the entrepreneur, one that pays limited attention to agents' embodied properties and powers and their variable capacity to accomplish a particular identity. This has a number of adverse consequences for theorising entrepreneurial identity. While we do not subscribe to strong essentialism, a degree of essentialism is necessary for the notion of the self and the idea that agents are capable of resisting discourse (O'Mahoney, 2012). Women entrepreneurs, for instance, often resist the masculine connotations of entrepreneurship (Essers and Benschop, 2007). Some studies illustrate that the body influences identity formation, but do not theorise its role explicitly (Haynie and Shepherd, 2011) or, alternatively, reduce the body to a discursive construct (Ainsworth and Hardy, 2008), with the consequence that entrepreneurs' embodied properties and powers are seriously undertheorised as an influence on identity. A number of studies do acknowledge embodiment to a degree. Down and Reveley (2004), for instance, highlight the role of non-linguistic practices, such as the ability to use particular technologies in relation to the practical environments, but they do not theorise how the body and embodied knowledge might influence such practices and the identities emergent from them. Haynie and Shepherd (2011) illustrate the devastating impact of injury on personal identity when the sense of self is closely linked to a career one is unable to retain as a result of impairment. While pointing out, importantly, that impairment can motivate entrepreneurial activities as well as shape experiences of it, they explore injury as a 'traumatic life event' rather than as a cause of impairment that materially affects embodied practices and identity formation.

The entrepreneurial identity literature is underpinned by a number of problematic assumptions that limit understanding of the meaning, formation and influence of identity on action. First, the body is an absent presence (Shilling, 2003) in most studies; it is always present in the interviewee/researcher interaction, but never a focus of investigation. Scholars therefore fail to explore explicitly the materiality of the body and its effects on entrepreneurial identity. Second, by taking the body for granted, entrepreneurs are treated implicitly as an homogeneous group, sharing identical properties and powers, rather than as uniquely embodied agents. In some respects, this mirrors the omission identified by studies of female and ethnic minority entrepreneurs that claim research has typically presupposed a white, male entrepreneur. Third, entrepreneurs are typically assumed to be able-bodied, equally capable of starting and operating a business, rather than differently-abled agents. $\left[{ }^{2}\right]$ Treating able-bodiedness implicitly as a stable attribute of entrepreneurs, studies paradoxically commit the very flaw of essentialism they reject 
in others. Entrepreneurs who do not fit the stereotypical image of an able-bodied person are largely invisible in the literature as a result. Recognising entrepreneurs as differently-abled is crucial for understanding identity and action.

\section{Implications of embodied entrepreneurial identity}

We have emphasised that human embodiment is a necessary precondition for the emergence of entrepreneurial identity as a particular set of concerns in the natural, practical and social environments. How we are embodied significantly shapes, and is shaped by, what we care about. Each person has a unique set of concerns, arising from their embodiment, which makes them a particular person. Creating and managing a business, and being committed to performing that social role successfully, as defined by the individual in relation to their concerns, is what makes one a particular entrepreneur. But what are the theoretical and methodological implications of this new conception of embodied entrepreneurial identity for future research?

Although our framework applies to all entrepreneurs, we focus on one group entrepreneurs with impairments - to elucidate how being embodied in a particular way shapes entrepreneurial identity. We begin by unpacking the concept of 'impairment' as a real social object, with particular properties and powers, capable of producing material effects, regardless of what we call it or how we observe it (Williams, 1999). Impairments have real effects on entrepreneurs' embodied practices and, therefore, on their identities. The capacity to create and operate a business may be influenced by multiple dimensions of impairment: by origin, type, severity, duration, and by whether impairments are a stable, long-term condition, degenerative or impose fluctuating or recurring restrictions on activity (Boyd, 2012). Diversity of impairments is usually overlooked in social research, especially in surveys that simply distinguish disabled and non-disabled respondents in binary terms, implicitly treating disabled people as an homogenous group (Pagán, 2009). Of course, impairments do not have determinate effects; much depends upon how entrepreneurs, and their stakeholders, adapt to their conditions. But what might be the implications of recognising the effects of diverse impairments on entrepreneurs' capabilities and practices, and hence their identities?

\section{Theoretical implications}

Identity formation involves a range of embodied linguistic and non-linguistic practices, which enable and constrain entrepreneurs to act in particular ways. While the studies reviewed predominantly emphasise the linguistic, more explicit consideration of non-linguistic practices can 
produce new insights into the effects of embodiment on entrepreneurs' capacities, concerns and actions. Researchers must attend to embodied properties and powers, including impairments and their effects in relation to the natural and practical as well as social environments (Archer, 2000), as each entrepreneur prioritises different concerns in each order of reality. In the social environment, building relationships with new customers, attracting investors and retaining employees are crucial for business creation and sustainability. In the practical order, driving a car or using various technologies may be as important as relationship building and will enable action in the social order. In the natural environment, the capacity to walk or to see and hear will inevitably shape dayto-day practices, with consequences for identity formation.

The three orders of reality (Archer, 2000) is an analytical distinction only, yet a powerful one for recognising how entrepreneurs' powers in the natural and practical orders might shape their capacities and concerns in the social order. The distinction between the three orders can help us to identify those concerns we usually take for granted when researching entrepreneuring. It can help us to avoid the assumed able-bodiedness and to consider how entrepreneuring might be done differently by differently-abled agents. Sensory, physical and cognitive impairments necessarily shape entrepreneurs' embodied knowledge and practices in terms of movement, using artefacts and technologies, and communicating with stakeholders, in very different ways. Individual experiences will of course vary with social context; some settings are more favourable to entrepreneurs with particular kinds of impairment than others. Understanding how particular impairments influence entrepreneurs in their natural and practical environments can provide new insights into their concerns and practices in their social environments. We discuss several examples to illustrate the potential effects of impairment on new venture creation and management.

While many people are constrained at start-up by their specific impairments and associated discriminatory practices (Boylan and Burchardt, 2002), others are motivated to pursue market opportunities they may not have discovered otherwise. Disabled people, studies suggest, are more likely to become self-employed than the population generally although this varies with type of impairment (Boylan and Burchardt, 2002; EMDA, 2009; Pagán, 2009). Acquiring an impairment as a result of accident or ill-health may force some to pursue a career change and motivate start-up (Haynie and Shepherd, 2011). People born with severe impairments may seek self-employment because of employment discrimination. Self-employment can offer an alternative source of income and provide the flexibility to fit paid work around other personal concerns or to help overcome negative labour market attitudes (Pagán, 2009).

Particular impairments might be stigmatising (Goffman, 1963) and shape entrepreneurs' 
attempts to present themselves as legitimate actors. All entrepreneurs have to access resources and markets in order to create and sustain a business. To do so, building and maintaining working relationships with powerful stakeholders is essential. Entrepreneurs make impressions on others both intentionally and unintentionally (Goffman, 1959). Narrative practices can help them to make the right impression with stakeholders and be perceived as legitimate actors (Lounsbury and Glynn, 2001). Non-linguistic practices, including the use of artefacts such as settings, props and dress, and bodily cues like expressiveness and gestures might influence entrepreneurs' ability to achieve support for novel ventures (Clarke, 2011; Cornelissen et al., 2012). Entrepreneurs with impairments may need to exert greater effort to achieve legitimacy (De Clercq and Voronov, 2009; Clarke, 2011) and to present a credible professional identity (Clarke, 2011), in order to 'fit in' and 'stand out' at the same time (De Clercq and Voronov, 2009). These entrepreneurs may not 'fit in' with the stereotypical image of an able-bodied entrepreneur, and 'stand out' unintentionally for the wrong reasons - for their impairment - with implications for their capacity to negotiate an entrepreneurial identity in interaction with significant stakeholders. The visibility of impairment is likely pose particular challenges. Entrepreneurs with highly visible impairments such as severe cerebral palsy may organise their business activities so as to minimise face-to-face contact with stakeholders, for example, by choosing to work at home. In contrast, entrepreneurs with 'hidden' impairments, such as chronic fatigue syndrome or dyslexia, might not experience the same pressures to minimise stakeholder contact - they may, of course, face different constraints on action arising from their impairment.

\section{Methodological implications}

Conflating entrepreneurial identity with linguistic practices, in our view, produces an impoverished and disembodied conception of the entrepreneur. Researchers should perhaps attend to three issues in addition to entrepreneurs' narrative and discursive practices: first, to study entrepreneurs' embodied properties and powers and the concerns they give rise to; second, to examine stakeholder perceptions of entrepreneurs' bodily appearance and capabilities; and, third, to explore how entrepreneurs interpret, and respond to, stakeholder reactions to their embodiment.

Methods such as interviewing can capture individuals' embodied, reflexive, lived experiences of starting and running a business. People with impairments might be particularly conscious of their embodiment in so far as it constrains their activities (Leder, 1990) and therefore better able to discuss their embodied properties and powers, and their likely effects, in a research 
interview. Entrepreneurship researchers rarely explore physical capabilities, including the use of artefacts, and the consequences for identity and action. Technology, for instance, plays an important role in human interaction; artefacts such as computers and telephones shape identities (Sandelowski, 2002). In the social order, respondents might reflect on how stakeholders react to their embodiment, and how such reactions affect their identity. To elucidate what is often taken for granted in narrative expressions of entrepreneurial identity, researchers need to tease out how embodiment shapes, and is shaped by, respondents' unique constellation of concerns. Asking entrepreneurs questions about the impact of their own bodies on their activities in the natural, practical and social orders can make their embodied concerns visible (Seymour, 2007).

Practices are often habitual, performed pre-reflexively without conscious deliberation. Ethnographic methods, including observation and videotaping, may be particularly useful to discover how entrepreneurs, as embodied agents, interact with their natural, practical and social environments. While some have used these methods to research entrepreneurial identity, studies did not focus specifically on impairment (Clarke, 2011) or on the body and embodied practices (Down, 2006). Entrepreneurs may be unaware of the effects of their embodiment on powerful stakeholders. Interviews with stakeholders, and observations of entrepreneur-stakeholder interaction, could provide novel and richer insights into the role of body in the formation of entrepreneurial identity. Watson (2008) provides an insightful account of the identity work of two managers, illustrating how they are 'read' by significant others in terms of their social identities, including gender and managerial identities. Although Watson implies that managers' particular embodied properties and powers influence how others perceive them, and how individuals think they are perceived by others, he under-theorises the influence of embodiment.

\section{Conclusion}

Human embodiment has largely been taken for granted or under-theorised in the entrepreneurial identity literature, limiting the scope and value of research. Prior work incorporates several problematic assumptions. Researchers typically treat entrepreneurs as an homogeneous group in terms of their embodied properties and powers, and assume they are able-bodied, rather than differently-abled, agents. We have critiqued the literature for its strong constructionist tendencies to conceptualise entrepreneurial identity primarily in terms of narrative and discursive practices. This line of thinking has produced a disembodied conception of the entrepreneur, although perhaps unintentionally. Identity cannot be reduced to linguistic performances. From our realist, moderate constructionist viewpoint, embodied linguistic and non-linguistic practices, such as 
movement, posture, gestures and facial expressions play a significant role in the formation of identity, with important consequences for action.

Drawing on the wider social sciences literature on identity, embodiment, impression management and stigma, we have proposed a new conception of entrepreneurial identity, as a unique constellation of concerns emergent from the embodied practices of agents committed to new venture creation and management. Embodiment enables as well as constrains agents' capacities, and shapes their concerns, in relation to their natural, practical and social environments. Entrepreneurs' capacities and concerns in the natural and practical order necessarily influence what they are capable of, and care about, in the social order. Their concerns exist and generate effects regardless of whether or not these are expressed linguistically in research interviews. Entrepreneurial identity, defined as a set of concerns, is communicated through non-linguistic as well as linguistic action.

The embodying of entrepreneurial identity has wider implications for the study of entrepreneurship. Entrepreneurial cognition research, for instance, acknowledges the embodied nature of cognitive processes (Mitchell et al., 2011; Grégoire et al., 2011); studying entrepreneurial orientations, motivations and decision-making without reference to the body will be incomplete. Categories such as 'mumpreneurs', male, female, ethnic minority, older and disabled entrepreneurs are of course socially and culturally constituted. That these particular identities emerge from embodiment is self-evident, but the materiality of such embodiment and its effects on identity is usually left implicit. Studies should theorise the influence of entrepreneurs' embodied properties and powers, whatever they may be, on identity. Entrepreneurs reason, sense, feel and act through their bodies in relation to their particular environments; accounts of identity will be incomplete without reference to embodiment. We have discussed the theoretical and methodological implications for studying one particular group - entrepreneurs with impairments - to elucidate how being embodied in particular ways shapes identity and, in turn, influences action. Researchers must attend explicitly to entrepreneurs' and stakeholders' embodied non-linguistic and linguistic practices in order to capture processes of identity formation and transformation.

\section{References}

Achtenhagen, L. and Welter, F. (2011), "'Surfing on the ironing board' - the representation of women's entrepreneurship in German newspapers", Entrepreneurship \& Regional Development: An 
International Journal, Vol. 23 Issue 9-10, pp. 763-786.

Ainsworth, S. and Hardy, C. (2008), "The enterprising self: an unsuitable job for an older worker", Organization, Vol. 15 No. 3, pp. 389-405.

Alvesson, M., Lee Ashcraft, K. and Thomas, R. (2008), "Identity matters: reflections on the construction of identity scholarship in organization studies", Organization, Vol. 15 No. 1, pp. 5-28.

Anderson, A. R. and Warren, L. (2011), "The entrepreneur as hero and jester: enacting the entrepreneurial discourse", International Small Business Journal, Vol. 29 No. 6, pp. 589-609.

Archer, M. (1995), Realist Social Theory, Cambridge University Press, Cambridge.

Archer, M. (2000), Being Human: The Problem of Agency, Cambridge University Press, Cambridge.

Bhaskar, R. (1978), A Realist Theory of Science, $2^{\text {nd }}$ ed., Harvester, Hassocks.

Bhaskar, R. (1979), The Possibility of Naturalism, Harvester Wheatsheaf, Brighton.

Boyd, V. (2012), "Are some disabilities more equal than others? Conceptualising fluctuating or recurring impairments within contemporary legislation and practice", Disability \& Society, Vol. 27 No. 4, pp. 459-469.

Boylan, A. and Burchardt, T. (2002), "Barriers to self-employment for disabled people", Report prepared for the Small Business Service.

Burkitt, I. (1999), Bodies of Thought: Embodiment, Identity and Modernity, Sage, London.

Clarke, J. (2011), "Revitalizing entrepreneurship: how visual symbols are used in entrepreneurial performances", Journal of Management Studies, Vol. 48 No. 6, pp. 1365-1391.

Cohen, L. and Musson, G. (2000), "Entrepreneurial identities: reflections from two case studies", Organization, Vol. 7 No.1, pp. 31-48. 
Cornelissen, J. P., Clarke, J. S. and Cienki, A. (2012), "Sensegiving in entrepreneurial contexts: The use of metaphors in speech and gesture to gain and sustain support for novel business ventures", International Small Business Journal, Vol. 30 No. 3, pp. 213-241.

Crossley, N. (2006), Reflexive Embodiment in Contemporary Society, Open University Press, Maidenhead.

Cunliffe, A. and Coupland, C. (2011), "From hero to villain to hero: making experience sensible through embodied narrative sensemaking", Human Relations, Vol. 65 No.1, pp. 63-88.

De Clercq, D. and Voronov, M. (2009), "Toward a practice perspective of entrepreneurship: entrepreneurial legitimacy as habitus", International Small Business Journal, Vol. 27 No. 4, pp. 395419.

Díaz García, M. C. and Welter, F. (2013), "Gender identities and practices: interpreting women entrepreneurs' narratives", International Small Business Journal, Vol. 31 No. 4, pp. 384-404.

Down, S. and Reveley, J. (2004), "Generational encounters and the social formation of entrepreneurial identity: 'Young Guns' and 'Old Farts', Organization, Vol. 11 No.2, pp. 233-250.

Down, S. (2006), Narratives of Enterprise: Crafting Entrepreneurial Self-Identity in a Small Firm, Edward Elgar, Cheltenham.

Down, S. and Warren, L. (2008), “Constructing narratives of enterprise: clichés and entrepreneurial self-identity", International Journal of Entrepreneurial Behaviour \& Research, Vol. 14 No. 1, pp. 423.

Down, S. (2010), "Entrepreneuring: explanations of the entrepreneurial self", in Down, S. (Ed.), Enterprise, Entrepreneurship and Small Business, Sage, London, pp. 57-77.

Elder-Vass, D. (2012), The Reality of Social Construction, Cambridge University Press, Cambridge. 
EMDA (2009), "Scoping study into the business support needs of disabled entrepreneurs in the East Midlands", A final report prepared by the Focus Consultants Ltd on behalf of the East Midlands Development Agency, June 2009.

Essers, C. and Benschop, Y. (2007), "Enterprising identities: female entrepreneurs of Moroccan or Turkish origin in the Netherlands", Organization Studies, Vol. 28 No.1, pp. 49-69.

Essers, C. and Benschop, Y. (2009), "Muslim businesswomen doing boundary work: the negotiation of Islam, gender and ethnicity within entrepreneurial contexts", Human Relations, Vol. 62 No. 3, pp. 403-423.

Farnell, B. and Varela, C. (2008), "The second somatic revolution", Journal for the Theory of Social Behaviour, Vol. 38 Issue 3, pp. 215-240.

Gibbs Jr., R. W. (2003), “Embodied experience and linguistic meaning”, Brain and Language, Vol. 84 Issue 1, pp. 1-15.

Giddens, A. (1991), Modernity and Self-Identity: Self and Society in the Late Modern Age, Polity Press, Cambridge.

Goffman, E. (1959), The Presentation of Self in Everyday Life, Pelican Books, Harmondsworth.

Goffman, E. (1963), Stigma: Notes on the Management of Spoiled Identity, Penguin Books, London.

Grégoire, D. A., Corbett, A. C. and J. S. McMullen (2011), "The cognitive perspective in entrepreneurship: an agenda for future research", Journal of Management Studies, Vol. 48 No. 6 , pp. 1443-1477.

Haynie, M. J. and Shepherd, D. (2011), "Toward a theory of discontinuous career transition: investigating career transitions necessitated by traumatic life events", Journal of Applied Psychology, Vol. 96 No.3, pp. 501-524.

Hytti, U. (2005), "New meanings for entrepreneurs: from risk-taking heroes to safe-seeking 
professionals", Journal of Organizational Change Management, Vol. 18 No.6, pp. 594-611.

Iyer, R. (2009), "Entrepreneurial identities and the problematic of subjectivity in media-mediated discourses", Discourse \& Society, Vol. 20 No. 2, pp. 241-263.

Jenkins, R. (2008), Social Identity ( $3^{\text {rd }}$ ed), Routledge, London.

Johansson, A. W. (2004), "Narrating the entrepreneur", International Small Business Journal, Vol. 22 No.3, pp. 273-293.

Jones, R., Latham, J. and Betta, M. (2008), "Narrative construction of the social entrepreneurial identity", International Journal of Entrepreneurial Behaviour \& Research, Vol. 14 No.5, pp. 330-345.

Lakoff, G. and Johnson, M. (1999), Philosophy in the Flesh: The Embodied Mind and its Challenge to Western Thought, Basic Books, New York.

Leder, D. (1990), The Absent Body, University of Chicago Press, Chicago.

Lounsbury, M. and Glynn, M. A. (2001), "Cultural entrepreneurship: stories, legitimacy, and the acquisition of resources", Strategic Management Journal, Vol. 22 Issue 6-7, pp. 545-564.

Martens, M. L., Jennings, J. E. and Devereaux Jennings, P. (2007), "Do the stories they tell get them the money they need? The role of entrepreneurial narratives in resource acquisition", Academy of Management Journal, Vol. 50 No. 5, pp. 1107-1132.

Mead, G. H. (1938), Mind, Self and Society, University of Chicago Press, Chicago.

Mitchell, R. K. (1997), "Oral history and expert scripts: demystifying the entrepreneurial experience", Journal of Management History, Vol. 2 Issue 3, pp. 50-67.

Mitchell, R. K., Randolph-Seng, B. and J. R. Mitchell (2011), “Dialogue: socially situated cognition: imagining new opportunities for entrepreneurship research", Academy of Management Review, Vol. 36 Issue 4, pp. 774-778. 
Navis, C. and Glynn, M. A. (2011), "Legitimate distinctiveness and the entrepreneurial identity: influence on investor judgements of new venture plausibility", Academy of Management Review, Vol. 36 No. 3, pp. 479-499.

Nicholson, L. and Anderson, A. R. (2005), "News and nuances of the entrepreneurial myth and metaphor: linguistic games in entrepreneurial sense-making and sense-giving", Entrepreneurship Theory and Practice, Vol. 29 Issue 2, pp. 153-172.

O’Mahoney, J. (2012), “Embracing essentialism: a realist critique of resistance to discursive power", Organization, Vol. 19 No. 6, pp. 723-741.

Pagán, R. (2009), "Self-employment among people with disabilities: evidence for Europe", Disability \& Society, Vol. 24 No. 2, pp. 217-229.

Reveley, J. and Down, S. (2010), "Stigmatization and self-presentation in Australian entrepreneurial identity formation" in Hjorth, D. and Steyaert, C. (Ed.), The Politics and Aesthetics of Entrepreneurship: A Fourth Movements in Entrepreneurship Book, Edward Elgar Publishing, Cheltenham.

Rouse, J. (2008), "The embodied entrepreneur: through the lens of pregnancy", In: 31st Institute for Small Business and Entrepreneurship (ISBE) Conference: International Entrepreneurship promoting excellence in education, research and practice; 5-7 Nov 2008, Belfast, U.K.

Rouse, J. (2009), "Can you hang on while I give birth and breastfeed? Individualisation, agency and oppression in entrepreneurs' maternity plans", In: 32nd Institute for Small Business and Entrepreneurship (ISBE) Conference: Celebrating 3 decades of excellence in education, research and practice: at the cutting edge of international entrepreneurship; 3-6 Nov 2009, Liverpool, U.K.

Sandelowski, M. (2002), "Reembodying qualitative inquiry", Qualitative Health Research, Vol. 12 No. 1 , pp. 104-115.

Sayer, A. (1992), Method in Social Science $\left(2^{\text {nd }}\right.$ ed), Routledge, London. 
Sayer, A. (1997), "Essentialism, social constructionism and beyond", The Sociological Review, Vol. 25 No. 3, pp. 453-487.

Seymour, W. (2007), "Exhuming the body: revisiting the role of the visible body in ethnographic research", Qualitative Health Research, Vol. 17 No. 9, pp. 1188-1197.

Shilling, C. (2003), The Body and Social Theory, Sage, London.

Smith, C. (2010), What Is a Person?: Rethinking Humanity, Social Life, and the Moral Good from the Person Up, University of Chicago Press, Chicago.

Smith, R. (2010), "Masculinity, doxa and the institutionalisation of entrepreneurial identity in the novel Cityboy", International Journal of Gender and Entrepreneurship, Vol. 2 No. 1, pp. 27-48.

Somers, M. R. (1994), "The narrative constitution of identity: a relational and network approach", Theory and Society, Vol. 23 No.5, pp. 605-649.

Sveningsson, S. and Alvesson, M. (2003), "Managing managerial identities: organizational fragmentation, discourse and identity struggle", Human Relations, Vol. 56 No. 10, pp. 1163-1193.

Turner, B. S. (1984), The Body \& Society: Explorations in Social Theory, Basil Blackwell, Oxford.

Varela, F. J., Thompson, E. and Rosch, E. (1991), The Embodied Mind: Cognitive Science and Human Experience, MIT Press, Cambridge, Mass.

Warren, L. (2004), “Negotiating entrepreneurial identity: communities of practice and changing discourses", International Journal of Entrepreneurship and Innovation, Vol. 5 No.1, pp. 25-35.

Watson, T. J. (2008), “Managing identity: identity work, personal predicaments and structural circumstances", Organization, Vol. 15 No.1, pp. 121-143.

Watson, T. J. (2009), "Entrepreneurial action, identity work and the use of multiple discursive 
resources: the case of rapidly changing family business", International Small Business Journal, Vol. 27 No. 3, pp. 251-274.

Williams, S. J. (1999), "Is anybody there? Critical realism, chronic illness and the disability debate", Sociology of Health \& IIIness, Vol. 21 No. 6, pp. 797-819.

\footnotetext{
${ }^{1}$ Entrepreneurs with impairments are the focus of the lead author's doctoral research.

'We recognise that terms like 'able-bodied', 'healthy' or 'normal' take on different meanings in different social and cultural contexts. Yet, we also recognise that such terms serve as necessary analytical categories without which the words like 'impaired' would be meaningless when applied to human bodies or persons (Smith C., 2010: 45n.)
} 